\title{
Sob o peso da maternidade
}

\section{Under the weight of motherhood}

\author{
Maria Terezinha Bretas Vilarino \\ Professora, Universidade Vale do Rio Doce. \\ Governador Valadares - MG - Brasil \\ tevilarino@yahoo.com.br
}

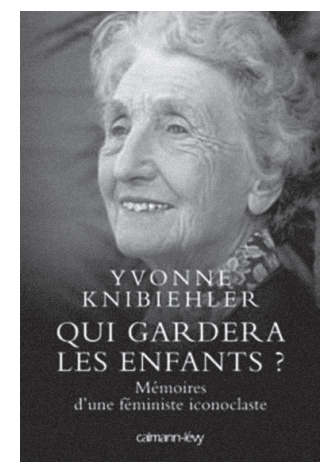

KNIBIEHLER, Yvonne. Quigardera les enfants? Mémoire d'une feministe iconoclaste. Paris: Calmann-Lévy. 2007. $320 \mathrm{p}$.
A questão levantada por Yvonne Knibiehler (2007) - "quem cuidará das crianças?" -, no livro Qui gardera les enfants? Mémoire d'une feministe iconoclaste, ultrapassa o universo doméstico/materno. A expansão do acesso das mulheres ao mundo do trabalho não lhes aliviou as tarefas e as preocupações domésticas e maternas, pois a maternidade representa, social e psicologicamente, mais "peso" para as mulheres que a paternidade para os homens. As mulheres trabalhadoras (intelectuais, operárias, vendedoras...), se forem donas de casa e mães, terão a dupla preocupação da casa e da rua, isto é, muitas mulheres/mães têm que "bricolar situações satisfatórias" para si, para os filhos e companheiros. Nesse contexto, embora esse livro de Yvonne Knibiehler tenha sido publicado em 2007, a discussão proposta se alinha com o debate acadêmico contemporâneo (e indispensável nos dias atuais) sobre a história das mulheres, da maternidade e das relações de gênero.

A indagação sobre "quem ficará com as crianças" descortina outras tensões: a dificuldade, para as mulheres, de conciliação entre maternidade e atividades profissionais; a mulher que trabalha fora de casa precisará de creches que recebam seus filhos/as; a incerteza sobre o cuidado amoroso e profissional nesses espaços; o silenciamento acerca dessas preocupações por receio de perda de espaço conquistado; o silenciamento a respeito de pressões, violências, assédios; o não reconhecimento de que o trabalho doméstico é também fonte de riqueza para a família, para a sociedade e para o Estado; a desconsideração previdenciária para com esse tipo de atividade.

A autora considera que o movimento feminista "errou ao desconsiderar esses dados", e não se intimidou em realçar essa inflexão. Yvonne Knibiehler fez questão de marcar a maternidade como peça especial da identidade feminina, e fazer da maternidade seu objeto de pesquisa não deixou de ser, na década de 1960, um desafio e uma audácia. As reações negativas aos enunciados de Knibiehler demonstram quanto o silenciamento sobre as 
questões acima serviam à manutenção do desequilíbrio de poderes nas relações homem/ mulher, seja no mundo da intimidade dos sexos ou no mundo do trabalho.

O que levou Yvonne Knibiehler a esse desafio audacioso? O lugar do qual fala é o de uma feminista repensando a maternidade, num movimento íntimo e engajado. Para pensar a experiência feminina, num mundo marcadamente masculinizado, Knibiehler busca na história francesa do final do século XIX e do início de século XX padrões modeladores das relações sexuais e familiares que distinguiam o comportamento (e o sentimento) de mulheres e homens daquelas gerações e seguintes, quando alguns desses marcos foram rescindidos.

A pesquisadora vai encontrar na história as referências conceituais e culturais para compreensão de seu dilema pessoal e historiográfico: o lugar social da maternidade, considerando-a para além da parturição. Nesse sentido, analisa a maternidade a partir do conceito de cidadania advindo do Iluminismo e da conjuntura da Revolução Francesa. O conceito de cidadania (re)inventado deu sentido novo para a maternidade: mulheres como "mães de cidadãos". Que distinção apresentava esse reconhecimento? Quais contradições escondia? A avaliação refinada de Yvonne Knibiehler descortina o paradoxo: os convencionais revolucionários excluem as mulheres da cidadania, mas concebem que no seio do seu lar serviriam à pátria. As mulheres não seriam suficientemente fortes para gestão das cidades, mas sua sensibilidade era importante para cuidar dos mais fracos/crianças. Ao mesmo tempo que entendem a natureza feminina como de cidadania secundária - sutil dominação masculina -, os homens querem filhos bem cuidados, para que eles, os pais, possam se dedicar à coisa pública. Forja-se, assim, uma ideologia dominante, que ignora a paternidade, e a relação com crianças/filhos é relegada à mãe.

O novo cenário é, todavia, reconfortante para as "mulheres/mães de cidadãos". Num plano simbólico, as mulheres se veem reabilitadas, requalificadas. A confortante publicação de livros sobre educação dos filhos, sobre educação doméstica, a explosão da literatura infantil, o surgimento de associações de damas ligadas à filantropia (futuras pré-escolas ou creches), atestam o valor da maternidade como "matriz" do povo do Estado-nação. Rousseau (2014), em Emílio ou da educação (1762), apresenta a preocupação com a educação da criança - que adulto vai se tornar: partícipe, cidadão, contribuinte? Rousseau traz a questão do cuidado e do afeto, do sagrado, colocando em evidência o laço entre mãe e filhos como agente essencial da civilização. As mães/mulheres dessa época, quanto menos dissociadas da função materna, mais são consideradas pelos filósofos, ou seja, a maternidade é despida de sua subjetividade e afetividade e imbuída dos valores da responsabilidade política e cidadã de preparar "bons cidadãos". A maternidade tomada como missão patriótica torna mais suportável seu peso.

Em busca dos significados para essas questões, Yvonne Knibiehler faz das memórias familiares uma fonte de inspiração e observação. Ao mirar-se na experiência de suas avós e mãe, encontra semelhanças e dessemelhanças quanto às relações afetivas, sociais e culturais que permeiam a questão do "feminino" e da maternidade na geração de cada uma. A autora busca elos de identidade em suas próprias memórias, que entrelaçam fragmentos de tempos vividos por diferentes gerações de mulheres e homens. Lembranças da intimidade familiar lhe são caras: tinha uma relação afetiva forte com a avó paterna; não ouviu as avós sobre 
seus partos, mas ouviu da mãe a respeito de seu próprio nascimento, penoso e difícil, com a avó paterna presente todo o tempo (o que foi odioso para a mãe, porque a autora nasceu menina, quando todos esperavam um menino).

Yvonne Knibiehler faz dessas e de outras lembranças familiares - temporadas nas casas de campo e praia, os banhos com prescrições higiênicas da época, a moral católica firme e envolvente que influenciava sua família - um lugar de reflexão, de pesquisa e de militância por um movimento feminista abrangente que considere a natureza materna em seu bojo e por políticas públicas que atendam esse movimento.

Enfim, a abordagem historiográfica desenvolvida por Yvonne Knibiehler pode ser considerada como uma escrita de si, um "ensaio de ego-história", na perspectiva discutida por Pierre Nora (1989). Isso posto, a leitura desse livro é recomendada a todos(as) que se preocupam com as questões do feminismo, de gênero, da maternidade, da família, e de todos os valores que lhes são agregados.

\section{REFERÊNCIAS}

KNIBIEHLER, Yvonne.

Qui gardera les enfants? Mémoire d'une feministe iconoclaste. Paris: Calmann-Lévy. 2007.

NORA, Pierre.

Ensaios de ego-história. Lisboa: Edições 70. 1989.
ROUSSEAU, Jean-Jacques.

Emílio ou da educação. São Paulo: Martins Fontes. 2014.

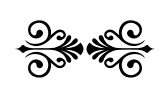

